\title{
Pemberdayaan ekonomi kelompok nelayan Desa Pangkah Kulon-Gresik dalam memproduksi kerupuk ikan sebagai upaya peningkatan nilai ekonomi ikan sortiran
}

\section{Muhammad Faisal Ibrahim, \& Ngatini*}

Universitas Internasional Semen Indonesia, Indonesia

*ngatini@uisi.ac.id

\begin{abstract}
Pangkah Kulon is one of the villages in Gresik Regency which is located in Ujung Pangkah District, Gresik, East Java. The lack of public knowledge about fish processing makes people required to be more creative in increasing the selling value of fish into processed products. So far, fresh fish caught by fishermen are sold directly to middlemen, while fresh fish that do not pass the sorting is simply thrown away. To increase the economic value of fish into high selling value products, training in the production of fish crackers is carried out. The training was conducted on the socialization of creative preparations, training on the manufacture and creative industry of fish crackers. In this training, participants (fishermen's wives) are trained to operate production equipment, from dough making, milling, to cutting. The knowledge and skills provided can be used as a pioneering effort for the fish cracker creative industry which is a favorite food for the community in general. In addition, it is also a business opportunity that can increase household income.
\end{abstract}

\begin{abstract}
Abstrak Pangkah Kulon adalah salah satu desa di Kabupaten Gresik yang terletak di Kecamatan Ujung Pangkah, Gresik, Jawa Timur. Minimnya pengetahuan masyarakat tentang pengolahan ikan membuat masyarakat dituntut untuk lebih kreatif dalam meningkatkan nilai jual ikan menjadi produk olahan. Selama ini ikan segar hasil tangkapan nelayan dijual secara langsung ke tengkulak, sedangkan ikan segar yang tidak lolos sortiran dibuang begitu saja. Dalam rangka meningkatkan nilai ekonomi ikan menjadi produk bernilai jual tinggi dilakukannya pelatihan produksi kerupuk ikan. Pelatihan dilakukan tentang sosialisasi olahan kreatif, pelatihan pembuatan dan industri kreatif kerupuk ikan. Dalam pelatihan ini peserta (ibu-ibu istri nelayan) dilatih untuk mengoperasikan alat produksi mulai dari alat pembuatan adonan, penggilingan, hingga alat pemotongan. Pengetahuan dan keterampilan yang diberikan dapat dijadikan sebagai upaya rintisan industri kreatif kerupuk ikan yang merupakan makanan favorit masyarakat pada umumnya. Selain itu, juga sebagai peluang usaha yang dapat meningkatkan pendapatan rumah tangga.
\end{abstract}

Keywords: fish cracker; sorting fish; pangkah kulon; gresik; fish cracker creative industry

\section{ठ OPEN ACCESS}

Citation: Ibrahim, M. F., \& Ngatini. (2021). Pemberdayaan ekonomi kelompok nelayan Desa Pangkah Kulon-Gresik dalam memproduksi kerupuk ikan sebagai upaya peningkatan nilai ekonomi ikan sortiran. Riau Journal of Empowerment, 4(3), 139-148. https://doi.org/10.31258/raje.4.3.139-148

Received: 2021-08-04 Revised: 2021-12-27 Accepted: 2021-12-27

Language: Bahasa Indonesia (id)

Funding: Kementerian Riset, Teknologi dan Pendidikan Tinggi Republik Indonesia

ISSN 2623-1549 (online), 2654-4520 (print)

(C) 2021 Muhammad Faisal Ibrahim, \& Ngatini. Author(s) retain the copyright of article published in this journal, with first publication rights granted to Riau Journal of Empowerment. The article is licenced under Creative Commons Attribution 4.0 International License. This license permits unrestricted use, distribution, and reproduction in any medium, provided the original author and source are credited. 


\section{PENDAHULUAN}

Gresik merupakan salah satu kabupaten di Jawa Timur yang memiliki sumber produksi perikanan yang besar. Selain itu, juga terletak secara geografis yang berdekatan dengan daerah pesisir di Laut Jawa (Narto, 2019). Jumlah produksi perikanan budidaya laut pada tahun 2020 mencapai 10.505.321 ton (Dinas Perikanan Kabupaten Gresik, 2020). Selain produksi perikanan budidaya laut, Gresik juga memiliki produksi budidaya perikanan di sektor tambak dan kolam. Jumlah produksi perikanan tangkap dari laut maupun perairan umum di Kabupaten Gresik pada tahun 2020 mencapai 11.115,37 ton (Dinas Perikanan Kabupaten Gresik, 2020). Tingginya jumlah hasil tangkapan ikan mempengaruhi jumlah produksi ikan segar, ikan yang sudah diawetkan maupun produksi olahan ikan dimana hal tersebut akan berpengaruh pada jumlah konsumsi ikan pada umumnya.

Ujung Pangkah merupakan salah satu kecamatan di Kabupaten Gresik yang terletak di sepanjang aliran sungai Bengawan Solo dengan potensi ikan cukup besar (Sudarno, dkk., 2015) dan sebagian besar merupakan pengrajin kerupuk mentah (Ihwah \& Setiyawan, 2018). Salah satu desa di Ujung Pangkah dengan masyarakat yang berprofesi sebagai nelayan adalah Desa Pangkah Kulon yang merupakan desa pesisir (Fuad, dkk., 2020). Sebagian besar masyarakat di sana berprofesi sebagai Nelayan, sehingga masyarakat sangat tergantung dengan kemajuan perikanan. Hasil tangkapan ikan sangat berpengaruh terhadap kesejahteraan nelayan serta berpengaruh pada pendapatan dari nelayan itu sendiri. Penghasilan sebagai seorang Nelayan tidak dapat dirasakan karena sangat bergantung dengan cuaca dan gelombang air laut. Usaha penangkapan ikan merupakan jenis kegiatan yang memiliki risiko ekonomi tinggi (Wiyono, 2012). Rata-rata Ibu-ibu istri dari para nelayan di Desa Ujung Pangkah Kulon berprofesi sebagai ibu rumah tangga biasa. Nelayan yang mencari ikan di laut tersebut biasanya langsung dijual ke tengkulak. Namun, para tengkulak hanya membeli ikan-ikan segar dan ikan yang penampilan luarnya bagus. Kondisi di lapangan menunjukkan bahwa ikan-ikan hasil tangkapan tidak selalu bagus (kondisi penampilan luarnya) dan juga tidak selalu memiliki nilai ekonomis tinggi (ikan jenis tertentu). Ikan hasil tangkapan merupakan ikan segar yang baru ditangkap dari laut dan proses penangkapannya pun tidak menggunakan bahan peledak atau bahan kimia sehingga masih terjaga kesegaran ikannya dan tidak terkontaminasi zat apapun. Begitu pula dengan ikan yang tidak lolos sortir oleh para tengkulak merupakan ikan yang masih segar hanya saja keadaan fisiknya kurang baik dan nilai jualnya rendah. Akibatnya ikan-ikan yang tidak lolos sortir tersebut dibuang begitu saja, sehingga para nelayan mengalami kerugian karena beberapa hasil tangkapan yang tidak sesuai dengan permintaan pasar. Di sisi lain masyarakat membutuhkan penghasilan tambahan selain dari penjualan hasil tangkapan ikan. Salah satu yang dapat dilakukan adalah mengembangkan industri kreatif olahan ikan (tidak lolos sortir tersebut), sehingga memiliki nilai tambah dan layak untuk dijual.

Salah satu makanan favorit masyarakat Indonesia adalah kerupuk yang merupakan lauk pendamping dari konsumsi makanan harian maupun sebagai makanan ringan (Ghazali, dkk., 2021). Kerupuk yang merupakan ciri khas makanan dari masyarakat di Indonesia serta didukung dengan kebiasaan masyarakat mengkonsumsi kerupuk merupakan peluang besar dalam mengembangkan usaha produk olahan kerupuk. Berdasarkan data dari BPS, Susenas pada tahun 2014-2018 yang menunjukkan jumlah rata-rata konsumsi kerupuk per kapita dalam seminggu mengalami kenaikan jumlah konsumsi (dapat dilihat pada Gambar 1). 


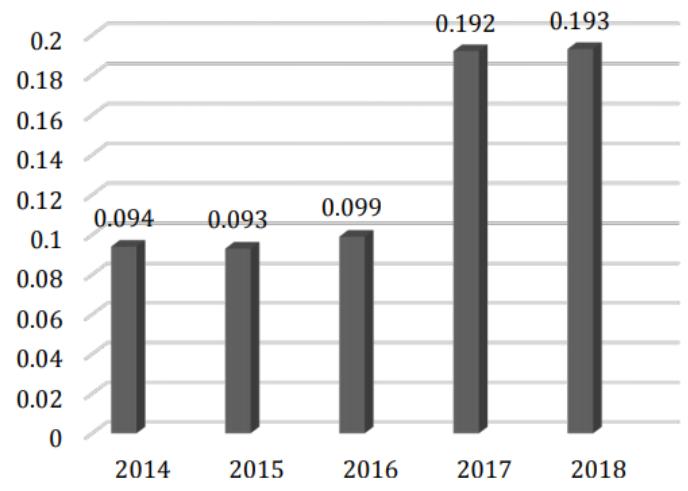

Ibrahim \&

Ngatini.

Gambar 1. Rata-rata Konsumsi Kerupuk per Kapita di Indonesia (Ons) (Sumber: BPS, Susenas 20142018)

Jumlah konsumsi kerupuk oleh masyarakat Indonesia yang semakin tinggi dalam kurun waktu lima tahun merupakan peluang besar bagi Desa Ujung Pangkah Kulon untuk mengembangkan produk industri kreatif olahan ikan berupa kerupuk ikan. Jumlah konsumsi ikan di Kabupaten Gresik dapat dilihat pada Gambar 2 berikut yang menunjukkan rata-rata konsumsi ikan per kapita pada tahun 2020 yaitu $39.21 \mathrm{~kg} / \mathrm{kapita} / \mathrm{tahun}$ dan jumlah konsumsi ini tergolong tinggi (Dinas Perikanan Kabupaten Gresik, 2020). Berdasarkan hal tersebut, guna untuk meningkatkan nilai tambah dari tangkapan ikan nelayan (yang tidak lolos sortir) dibuatlah pelatihan pembuatan kerupuk ikan sebagai rintisan industri kreatif olahan ikan di Desa Ujung Pangkah Kulon. Sasaran dari pelatihan tersebut lebih diperuntukan bagi ibu-ibu yang suaminya berprofesi sebagai nelayan. Pemberdayaan bagi Ibu-ibu di Desa Ujung Pangkah Kulon Kecamatan Ujung Pangkah, Kabupaten Gresik diharapkan menjadi rintisan awal usaha Kerupuk Ikan untuk mendukung industri kreatif.

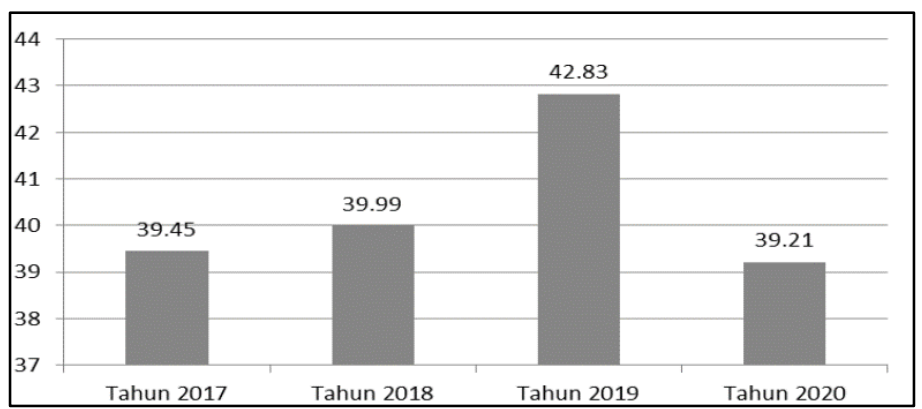

Gambar 2. Jumlah Angka Konsumsi Ikan Kab. Gresik (kg/kapita/tahun) (Sumber: Dinas Perikanan Kabupaten Gresik, 2020)

\section{METODE PENERAPAN}

Sasaran dari pelaksanaan pengabdian masyarakat ini adalah ibu-ibu Desa Pangkah Kulon, Gresik. Masyarakat yang tinggal di pesisir memiliki mata pencaharian terbesar sebagai nelayan dan petani tambak (Santoso, dkk, 2019). Pelaksanaan kegiatan diikuti oleh 15 orang ibu-ibu yang sangat antusias mengikuti sosialisasi produk olahan kreatif berbahan dasar ikan hingga pelatihan proses produksi kerupuk ikan. Bentuk kegiatan pengabdian masyarakat yang dilakukan terhadap Ibu-ibu istri para nelayan di desa Ujung Pangkah yaitu sebagai berikut: 


\section{Sosialisasi Olahan Kreatif}

Sosialisasi mengenai olahan kreatif disini sangat penting untuk mengenalkan masyarakat tentang apa itu Kerupuk Ikan. Dalam sosialisasi tersebut dilengkapi dengan modul yang nantinya dapat dibaca dan dipelajari secara mandiri oleh Ibu-ibu Desa Pangkah Kulon. Dari sosialisasi ini dilakukan pre-test dan post-test mengenai seberapa jauh masyarakat memahami tentang proses produksi olahan kreatif kerupuk ikan. Pre-test dan post-test tersebut dilakukan melalui pengisian kuesioner oleh Ibu- ibu.

\section{Pelatihan cara pembuatan}

Proses pembusukan ikan berlangsung sangat cepat, sehingga proses pengolahan ikan penting untuk diketahui masyarakat (Thaib, dkk, 2021). Tahap selanjutnya setelah masyarakat mengetahui dan mengenal apa itu Kerupuk Ikan adalah diadakannya pelatihan cara membuat Kerupuk Ikan bagi Ibu-ibu istri para nelayan di Desa Pangkah Kulon. Dalam pelatihan tersebut dijelaskan mengenai cara memisahkan duri dan kulit ikan, menghaluskan daging ikan, mencampur ikan dengan bahan yang lain, mengiris adonan ikan, hingga menjemur adonan ikan dengan baik dan benar. Setelah dilaksanakannya pelatihan tersebut, Ibu-ibu akan melaksanakan proses pembuatan kerupuk Ikan. Dalam pelatihan tersebut nanti Ibu-ibu akan diberikan beberapa ikan tidak lolos sortir yang nantinya diolah dan menghasilkan kerupuk ikan.

\section{Pelatihan tentang Industri Kreatif Kerupuk Ikan}

Tujuan jangka panjang dari pelatihan tersebut adalah terciptanya iklim Industri Kreatif Kerupuk Ikan di lingkungan Desa Pangkah Kulon dengan penggeraknya adalah Ibu-ibu istri para nelayan Desa Ujung Pangkah (KUB Pangkah Kulon). Dalam industri kreatif tersebut Ibuibu dibekali mengenai proses pemasaran baik secara offline maupun digital marketing.

Alat yang dibutuhkan dalam pembuatan kerupuk ikan antara lain yaitu pisau, talenan, panci, alat pengaduk, kompor serta ampan atau wadah pengering. Langkah-langkah proses pembuatannya adalah sebagai berikut (Ghazali, dkk. 2021):

1. Persiapkan alat dan bahan untuk membuat kerupuk ikan

2. Kupas kulit dan pisahkan duri ikan agar dapat di ambil dagingnya

3. Daging Ikan ditumbuk dengan halus kemudian ditambahkan bumbu yakni garam, gula dan air secukupnya

4. Tambahkan Tepung Tapioka dan Telur kemudian adonan diaduk sampai merata dan padar

5. Adonan dibentuk bulat panjang seperti lontong

6. Lontong adonan tersebut di kukus selama 2 jam

7. Setelah matang, diangkat dan dibiarkan dingin

8. Lontongan tersebut diiris tipis-tipis

9. Irisan lontongan tersebut kemudian dijemur selama 2-3 hari

10. Setelah kering, kerupuk ikan siap untuk di jual. 


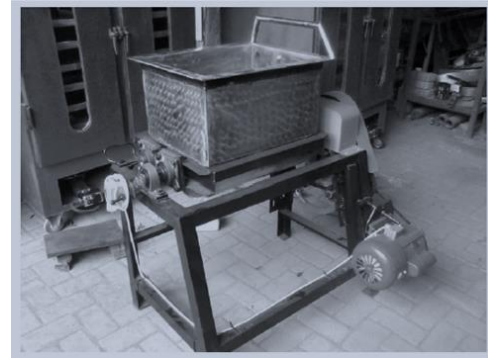

Penggiling

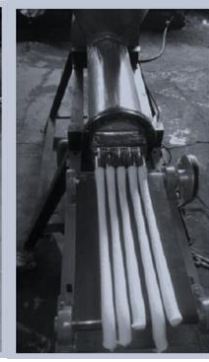

b. Pencetak

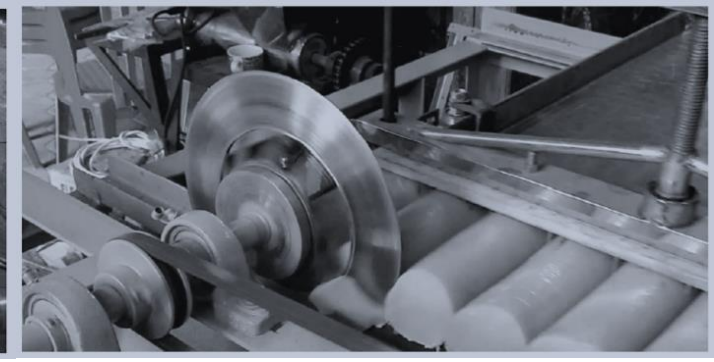

c. Pemotong
Ibrahim \&

Ngatini.

Gambar 3. Alat Produksi Olahan Kreatif Kerupuk Ikan

\section{HASIL DAN KETERCAPAIAN SASARAN}

\section{Sosialisasi Olahan Kreatif dan Pelatihan Pembuatan Kerupuk Ikan}

Sosialisasi olahan Kreatif dan pelatihan pembuatan kerupuk ikan diikuti oleh 15 peserta pelatihan yang merupakan ibu-ibu dari istri nelayan di Desa Pangkah Kulon, Gresik (dokumentasi kegiatan dapat dilihat pada Gambar 4). Sosialisasi diawali dengan dilakukannya pengumpulan informasi terkait tingkat pemahaman ibu-ibu di Desa Pangkah Kulon tentang peningkatan nilai jual dari produk olahan ikan. Survei tersebut merupakan pre-test yang dilakukan di awal sosialisasi dan sebelum pelatihan. Pre-test dilakukan untuk mengetahui tingkat pemahamanan dari peserta. Hasil survei menunjukkan beberapa produk olahan ikan makan menurut ibu-ibu yang dapat diproduksi dari ikan antara lain yaitu amplang, abon hingga kerupuk.

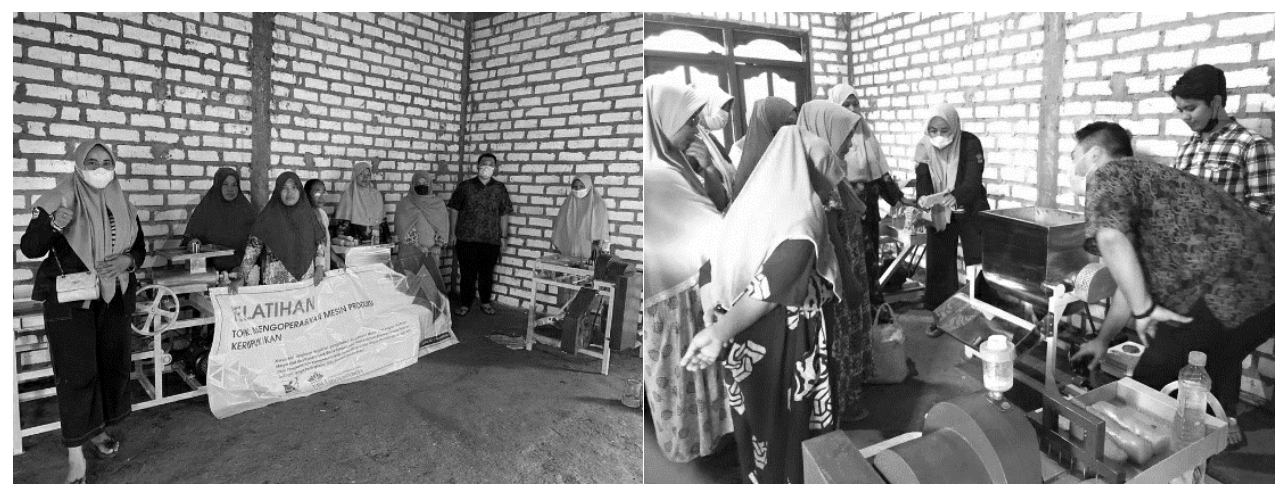

Gambar 4. Sosialisasi Olahan Kreatif dan Pelatihan Pembuatan Kerupuk Ikan

Sebelum dilakukan pelatihan pembuatan kerupuk ikan, peserta dibekali dengan materi tentang olahan kreatif yang kemudian dilanjutkan dengan pelatihan pembuatannya. Secara keseluruhan antusias dari peserta sangat tinggi dalam mengikuti pelatihan. Proses pelatihan dimulai dari persiapan bahan yang kemudian dibuat adonan melalui mesin produksi, hingga terbentuk adonan yang siap dipotong oleh mesin (Gambar 5). 


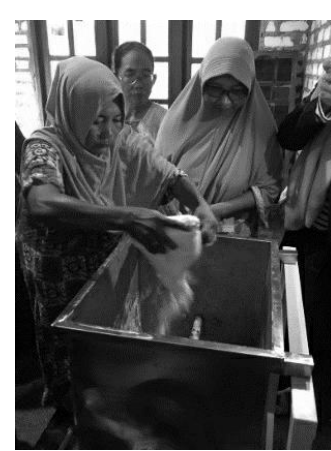

(a)

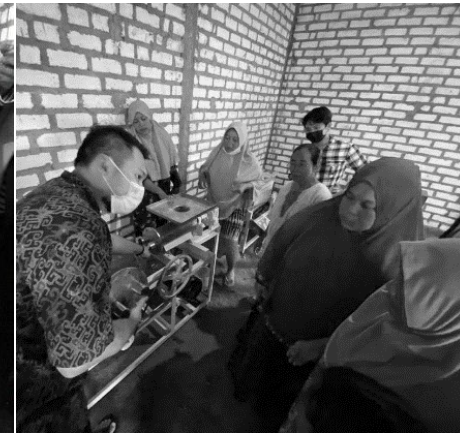

(b)

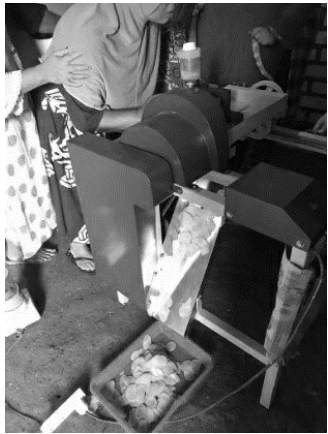

(c)

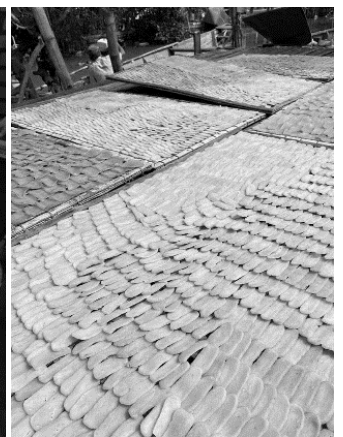

(d)

Gambar 5. Proses Pembuatan Kerupuk Ikan (a). Penggilingan adonan; (b). Pencetakan; (c). Pemotongan adonan; (d). Pengeringan

\section{Pelatihan tentang Industri Kreatif Kerupuk Ikan}

Dari hasil kuesioner diketahui mayoritas responden belum pernah mendapatkan pengetahuan tentang manajemen usaha industri kreatif. Terlebih lagi responden tidak dapat menentukan nilai jual suatu produk. Dengan begitu, penulis mendesain materi pelatihan sesuai dengan kebutuhan dan sasaran. Pada pelatihan ini juga diberikan materi mengenai cara menentukan harga jual minimum. Untuk menunjang proses manajemen dalam mengembangkan UMKM kerupuk ikan, maka perlu dilakukan pelatihan manajemen usaha industri kreatif. Mayoritas peserta sudah pernah berjualan namun masih minim pengetahuan dalam hal manajemen usaha. Dengan begitu, sering kali produk yang dijual menjadi kurang dapat bersaing dengan kompetitornya. Pada pelatihan ini materi disampaikan oleh tim pengabdian masyarakat dengan topik seputar pentingnya manajemen usaha untuk keberlanjutan usaha, cara menghitung harga pokok produksi, serta pemasaran. Penulis juga membuatkan template excel sederhana untuk perhitungan HPP yang dapat dilakukan melalui smartphone.

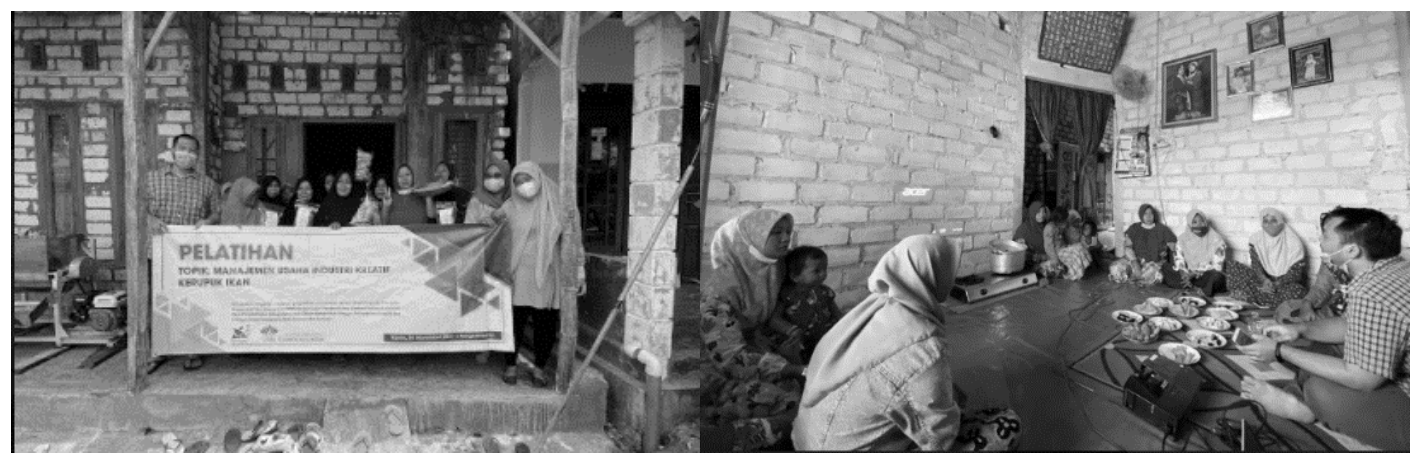

Gambar 6. Pelatihan Manajemen Usaha

Capaian pengembangan industri kreatif yang telah dilaksanakan adalah telah berlangsungnya dengan lancar kegiatan sosialisasi olahan kreatif, pelatihan cara pembuatan kerupuk dan pelatihan tentang industri kreatif melalui pelatihan manajemen usaha industri kreatif. Produk yang dihasilkan diberi nama yaitu "kerupuque", dapat dilihat pada Gambar berikut dan telah dipasarkan secara offline maupun online melalui platform shopee dan juga Instagram. 


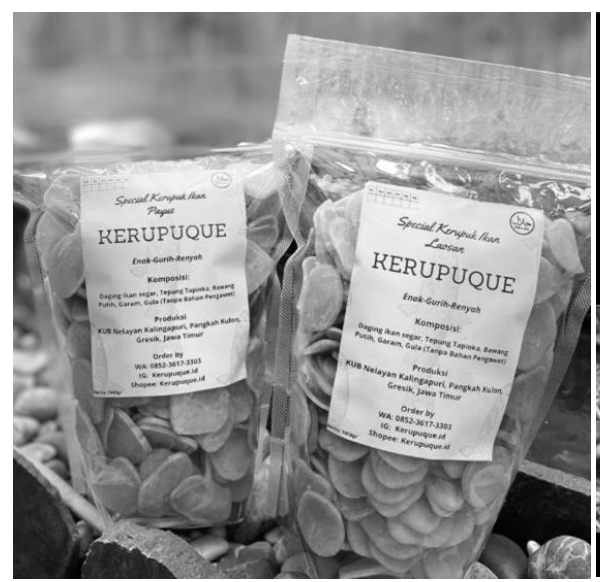

(a)

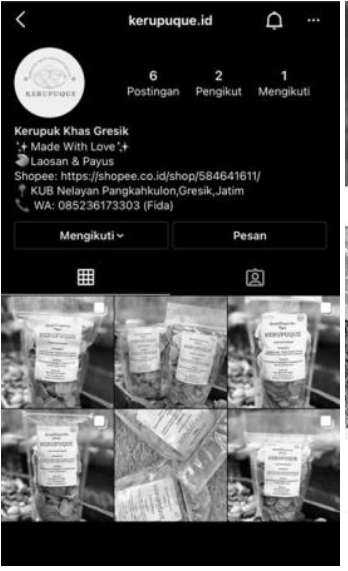

(b)

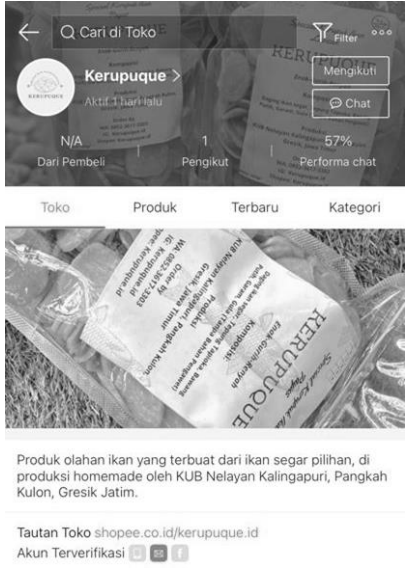

(c)

Gambar 7. (a). Produk “Kerupuque"; Media Jualan Online (b) Instagram dan (c) Shopee

\section{Capaian pemahaman peserta}

Pemahaman ibu-ibu tentang pentingnya nilai jual dari produk olahan ikan dapat dilihat pada Gambar 8. Pertanyaan yang diberikan adalah "Aktivitas berikut yang dapat meningkatkan nilai jual ikan adalah". Dengan pilihan jawaban adalah sebagai berikut:

a) Menjual ikan hasil tangkap secara curah

b) Membagikan ikan hasil tangkap secara gratis kepada awak kapal

c) Mengolah ikan hasil sortir menjadi produk olahan

d) Membuang ikan hasil sortir karena tidak laku dijual

e) Melakukan penangkapan ikan secara berlebih

Jawaban yang tepat untuk pertanyaan tersebut adalah d) Mengolah ikan hasil sortir menjadi produk olahan. Gambar 8 menunjukkan hanya 64\% ibu-ibu menjawab dengan benar, sedangkan 36\% lainnya menjawab salah. Sebanyak 36\% Ibu-ibu beranggapan bahwa aktivitas yang dapat meningkatkan nilai jual ikan adalah "Menjual ikan hasil tangkap secara curah", sedangkan 64\% lainnya menjawab dengan benar bahwa mengolah ikan hasil sortir menjadi produk olahan dapat meningkatkan nilai jual ikan. Setelah dilakukannya sosialisasi tentang pentingnya pengolahan ikan hasil sortir dan langkah-langkah dalam pembuatan kerupuk ikan menunjukkan bahwa seluruh ibu-ibu (100\%) telah memahami bahwa salah satu cara untuk meningkatkan nilai jual dari ikan adalah melalui pengolahan ikan hasil sortir menjadi sebuah produk olahan, sehingga ikan tidak jual serta merta apalagi ikan sortir yang dibiarkan dan tidak diolah menjadi produk apapun (Gambar 9).

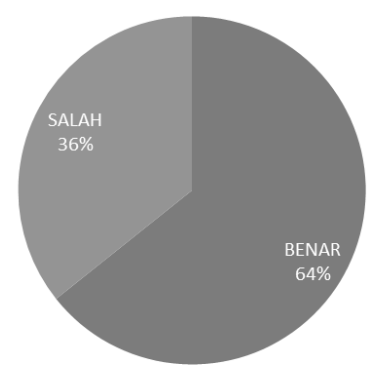

Gambar 8. Jawaban Pre-Test tentang Pemahaman Nilai Jual Produk Olahan Ikan 


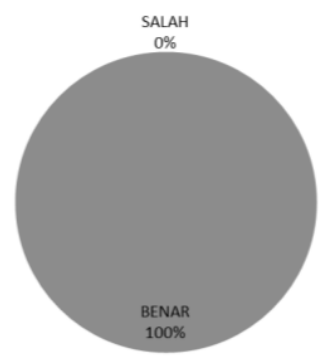

Gambar 9. Jawaban Post-Test tentang Pemahaman Nilai Jual Produk Olahan Ikan

Salah satu produk olahan ikan yang digemari oleh masyarakat adalah krupuk ikan yang merupakan snack favorit maupun sebagai pelengkap makanan. Sebelum adanya pelatihan dilakukan survey terlebih dahulu mengenai pengetahuan ibu-ibu tentang proses pembuatan kerupuk ikan dengan menggunakan alat produksi. Hal tersebut dapat dilihat pada Gambar 10 yang menjelaskan mengenai kemampuan peserta dalam mengolah kerupuk ikan sebelum dilakukannya pelatihan. Kuesioner tersebut menunjukkan bahwa sebanyak $70 \%$ ibu-ibu tidak mengetahui cara penggunaan alat produksi kerupuk ikan, sedangkan 30\% yang lainnya mengetahui cara penggunaan alat produksi kerupuk ikan namun masih kurang tepat. Hasil survei tersebut menunjukkan bahwa belum adanya pengalaman bagi ibu-ibu dalam proses pengolahan kerupuk ikan dengan menggunakan mesin produksi, sehingga diperlukannya pelatihan dalam pembuatan kerupuk ikan. Dalam kegiatan ini, seluruh alat produksi diberikan kepada KUB Nelayan Pangkah Kulon yang terdiri dari mesin penggiling, pencetak dan pemotong. Alat tersebut digunakan selama pelatihan dan kedepannya dapat dioperasikan oleh kelompok ibu-ibu istri nelayan secara kontinu.

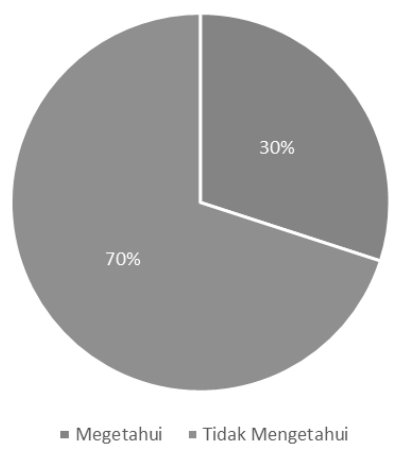

Gambar 10. Persentase Pengalaman Penggunaan Alat Produksi Kerupuk Ikan

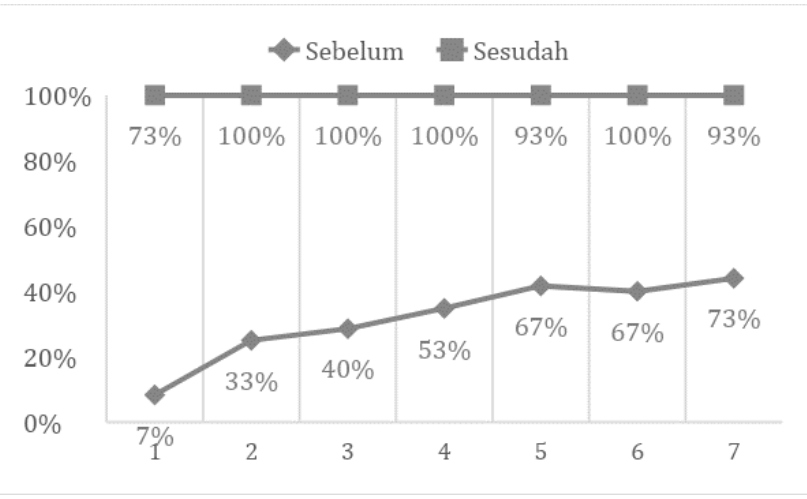

Gambar 11. Persentase Peningkatan Pemahaman Dasar Peserta Pelatihan 
Pemahaman dasar pelatihan dilakukan sebelum dan sesudah pelatihan dapat dilihat pada Gambar 11 tentang proses untuk mengurangi kerusakan pada ikan hasil tangkap, upaya yang dapat dilakukan untuk menghambat penurunan mutu ikan hasil tangkap, aktivitas yang dapat dilakukan untuk meningkatkan nilai jual ikan, dan produksi olahan ikan. Dari gambar tersebut dapat dilihat perbedaan yang sangat signifikan sebelum dan sesudah pelatihan. Hasil post-test

Ibrahim \& Ngatini. (tes akhir) pelatihan menunjukkan bahwa $100 \%$ peserta mengetahui tentang peningkatan nilai jual ikan menjadi produk olahan dan produksi ikan menjadi kerupuk ikan. Luaran yang diharapkan setelah melaksanakan pemberdayaan Ibu-ibu tentang pembuatan kerupuk ikan adalah terampilnya ibu-ibu istri para nelayan di Desa Pangkah Kulon dalam membuat Kerupuk Ikan. Dengan harapan ibu-ibu mampu menghasilkan olahan kreatif yang mampu meningkatkan perekonomian dan tambahan pendapatan. Setelah langkah ini tercapai, harapannya ibu-ibu bisa membuat industri kreatif olahan Kerupuk Ikan sebagai usaha mandiri ibu-ibu istri nelayan di Desa Pangkah Kulon.

Pemberdayaan bagi Ibu-ibu di Desa Pangkah Kulon, Kecamatan Ujung Pangkah, Kabupaten Gresik tentang Kerupuk Ikan diharapkan menjadi rintisan awal usaha Kerupuk Ikan untuk mendukung industri kreatif sehingga mampu mendukung perekonomian nelayan khususnya ibu-ibu istri dari para nelayan di desa Ujung Pangkah. Kemudian melalui kegiatan ini dapat digunakan untuk mensosialisasikan Kerupuk Ikan sebagai upaya pelestarian budaya dengan tahap awal di desa Pangkah Kulon, Gresik. Melalui sosialisasi tersebut, dilanjutkan dengan pelatihan pembuatan Kerupuk Ikan dan praktik langsung. Selanjutnya, pelatihan ini diharapkan dapat menjadi rintisan industri kreatif masyarakat, khususnya ibu-ibu istri dari para nelayan di desa Ujung Pangkah. Beberapa kegunaan dari kegiatan ini diantaranya adalah sebagai berikut:

1. Sebagai pelatihan untuk ibu-ibu istri nelayan di desa Pangkah Kulon dalam membuat Kerupuk Ikan.

2. Sebagai pembekalan keahlian untuk ibu-ibu istri nelayan dalam pembuatan Kerupuk Ikan selain sebagai Ibu Rumah Tangga.

3. Sebagai buah tangan (oleh-oleh) khas Desa Pangkah Kulon yang dibuat sendiri oleh ibuibu istri para nelayan.

4. Sebagai rintisan awal industri Kreatif Kerupuk Ikan oleh ibu-ibu istri nelayan, sehingga para istri nelayan juga dapat berpenghasilan dari usaha mandiri Kerupuk Ikan

\section{KESIMPULAN}

Pemberdayaan Ibu-ibu di Desa Pangkah Kulon, Kecamatan ujung Pangkah, Kabupaten Gresik telah mampu meningkatkan pengetahuan dan keterampilan dalam proses pengolahan kerupuk ikan melalui serangkaian kegiatan mulai dari sosialisasi olahan kreatif, pelatihan pembuatan kerupuk ikan hingga pelatihan industri kreatif kerupuk ikan. Hasil dari pelatihan tersebut berupa produk kerupuk ikan "kerupuque" yang telah dipasarkan secara offline dan online melalui shopee dan Instagram. Sejumlah $70 \%$ ibu-ibu yang sebelumnya tidak mengetahui bagaimana proses produksi kerupuk ikan menjadi $100 \%$ peserta memahami dan mampu mengoperasikan alat produksi kerupuk ikan. Proses pengolahan kerupuk ikan terdiri dari tahap pembuatan adonan, penggilingan, pemotongan hingga pengeringan. Pelatihan yang diberikan dapat menjadi bekal untuk rintisan industri kreatif kerupuk ikan oleh ibu-ibu nelayan sebagai penghasilan tambahan dan peningkatan nilai jual dari ikan sortiran. 


\section{UCAPAN TERIMA KASIH}

Penulis menyampaikan ucapan terima kasih kepada Kementerian Riset, Teknologi dan Pendidikan Tinggi dalam pendanaan hibah program pengabdian masyarakat skema Program Kemitraan Masyarakat (PKM) Tahun 2020. Terima kasih Penulis sampaikan ula terhadap Lembaga Penelitian dan Pengabdian Masyarakat (LPPM) Universitas Internasional Semen Indonesia (UISI), dan KUB Nelayan Pangkah Kulon, Gresik.

\section{Daftar Pustaka}

1. BPS (Badan Pusat Statistik). (2018). Pengeluaran untuk Konsumsi Penduduk Indonesia Berdasarkan Hasil Susenas Maret 2018. Jakarta: BPS.

2. Dinas Perikanan Kabupaten Gresik. (2020). Laporan Akuntabilitas Kinerja Instansi Pemerintah (LKj-IP) Dinas Perikanan Kabupaten Gresik Tahun 2020. https://gresikkab.go.id/ diakses pada tanggal 27 Juni 2021.

3. Fuad, M. A. Z., Iranawati, F., Kartikaningsih, H., Rosalina, K. (2020). Peningkatan Produksi dan Kualitas Produk Unggulan Kerupuk Ikan Desa Pangkahkulon Kecamattan Ujung PangkahGresik Jawa Timur. Pengabdianmu: Jurnal Ilmiah Pengabdian Masrayakat, 5(2), 203-209. DOI: https://doi.org/10.33084/pengabdianmu.v5i2.1045

4. Ghazali, M., Rabbani, R., Sari, M., Rohman, M. H., Nasiruddin, M. H., Suherman., \& Nurhayati. (2021). Pelatihan Pengolahan Kerupuk Ikan di Desa Ekas Buana Kecamatan Jerowaru Kabupaten Lombok Timur. Jurnal Pengabdian Magister Pendidikan IPA, 4(2), 93-98. DOI: https://doi.org/10.29303/jpmpi.v4i2.683

5. Ihwah, A. Z., dan Setiyawan, D. T. (2018). IbM UKM Kerupuk Ikan di Desa Pangkah Wetan Kecamatan Ujung Pangkah Kabupaten Gresik Jawa Timur. Jurnal Akses Pengabdian Indonesia, 3(1), 1-6. DOI: https://doi.org/10.33366/japi.v3i1.638

6. Narto. (2019). Pengembangan Produk Kerupuk Ikan Bandeng di Kabupaten Gresik dengan Menggunakan Metode Quality Function Deployment (QFD). Kaizen: Management Systems \& Industrial Engineering Journal, 2(2), 40-46. DOI: http://doi.org/10.25273/kaizen.v2i2.5956

7. Santoso, N., Nugraha, R. P., Andalas, R. (2019). Nilai Ekonomi Total Hutan Mangrove Kawasan Desa Pangkah Kulon dan Pangkah Wetan, Kecamatan Ujungpangkah, Kabupaten Gresik, Provinsi Jawa Timur. Media Konservasi, 24(2), 152-162. DOI: https://doi.org/10.29244/medkon.24.2.152-162

8. Sudarno, Mahasri G., dan Kismiyati. (2015). IbM Bagi Petambak Udang Tradisional di Desa Pangkah Wetan Kecamatan Ujung Pangkah, Kabupaten Gresik, Yang Mengalami Gagal Panen Secara Terus Menerus. Jurnal Ilmiah Perikanan dan kelautan, 7(1), 7-15. DOI: http://dx.doi.org/10.20473/jipk.v7i1.11220

9. Thaib, A., Nurhayati, Nazlia, S., Zuhrayani, R., Alfis, N. F., Syahputra, F., Handayani, L., Putri, N., Nurrahmah, Firdaus, Apriliani, D., Naufal, A. (2021). Pelatihan Pengolahan Kerupuk Ikan Tongkol: Upaya Meningkatkan Ketahanan Pangan Masyarakat Gampong Tibang Kecamatan Syiah Kuala Kota Banda Aceh Provinsi Aceh. Jurnal Abdimas UNAYA, 2(1), 6-11. http://jurnal.abulyatama.ac.id/index.php/Abdimas/article/view/1819

10. Wiyono, Eko Sri. (2012). Pengaruh Lama Melaut dan Jumlah Hauling terhadap Hasil Tangkapan Ikan pada Perikanan Gillnet Skala Kecil di Pekalongan Jawa Tengah. Jurnal Teknologi Perikanan dan Kelautan, 3(2), 57-64. DOI: https://doi.org/10.24319/jtpk.3.57-64 